\title{
PELATIHAN ASPEK MARKETING MIX UNTUK USAHA KERAJINAN TANGAN DALAM PEMANFAATAN POTENSI ALAM BINTAN DI KECAMATAN BINTAN UTARA
}

\section{Training Aspects Of Marketing Mix For Handicraft Business In The Utilization Of Natural Potential Of Bintan In North Bintan District}

\author{
Iranita $^{1}$, Kiki Wulandari ${ }^{1}$ \\ ${ }^{1}$ Program Studi Manajemen, Fakultas Ekonomi, Universitas Maritim Raja Ali Haji, \\ Tanjungpinang \\ *Korespondensi : iranita@umrah.ac.id
}

\begin{abstract}
ABSTRAK
Untuk menciptakan ekonomi kreatif dibutuhkan kerjasama oleh seluruh pihak baik pemerintah, para intelektual dan dunia pengusaha. Pemerintah bertugas menetapkan regulasi yang berkaitan dengan ekonomi kreatif dan memberikan ruang kepada masyarakat untuk menggali kreatifitas masyarakat yang bisa bersumber dari nilai budaya daerah masing-masing. Salah satu lini bisnis di Indonesia yang memiliki perkembangan cukup baik adalah bisnis kerajinan tangan. Hal ini dikarenakan kekayaan alam yang berlimpah terutama hasil laut di Indonesia, sehingga banyak produk dibuat kerajinan tangan dengan pemanfaatan limbah hasil laut. Inilah yang kemudian mendorong banyak pihak untuk mencoba peluang bisnis yang satu ini. Salah satu nya adalah Kelurahan Tanjung Uban Utara Kecamatan Bintan Utara Kabupaten Bintan Kepulauan Riau. Cukup beragam produk kerajinan tangan yang dihasilkan terutama Kelurahan Tanjung Uban Utara. Usaha ekonomi masyarakat itu yang memiliki potensi untuk dipasarkan dan dikembangkan dengan manajemen pemasaran yang lebih luas. Bentuk yang ada sudah bagus, dan perlu ditingkatkan lagi khususnya yang menyangkut produk, harga, promosi dan distribusinya. Desain kerajinan tangan masyarakat cukup menarik dan perlu ditingkatkan penjualan di pasar, baik pasar lokal maupun potensi pasar luar negeri, sehingga potensi pasar semakin luas. Strategi yang diterapkan untuk memasuki pasar adalah bauran pemasaran (marketing mix), bagaimana produk bisa memiliki keunggulan bersaing dan diminati konsumen.
\end{abstract}

Kata kunci : Aspek marketing mix, Kecamatan Bintan Utara, kerajinan tangan hasil laut

\begin{abstract}
To create a creative economy it takes cooperation by all parties of both the Government, the intellectuals and the world entrepreneurs. The government is tasked with establishing regulations relating to the creative economy and giving the community the space to explore the creativity of society that can be sourced from the cultural values of their respective regions. One of the business lines in Indonesia that has good development is the handicraft business. This is due to the abundant natural wealth, especially the seafood in Indonesia so that many products are made handicrafts with the utilization of marine waste. This is what then encourages many Parties to try out this one business opportunity. One of his villages is Tanjung Uban Utara District North Bintan District, Riau Islands. Quite a variety of handicraft products produced mainly Tanjung Uban Utara village. The Community's economic efforts have the potential to
\end{abstract}


be marketed and developed with broader marketing management. The existing shapes are good and need to be improved especially about product, price, promotion and distribution. The design of handicraft society is quite interesting and needs to be improved sales in the market, both the local market and the potential foreign market so that the market potential is wider. The strategy applied to enter the market is the marketing Mix (marketing mixed), how the product can have competitive advantages and demand for consumers

\section{Keyword : Marketing mix, marine handicrafts, North Bintan District}

\section{PENDAHULUAN}

Untuk menciptakan ekonomi kreatif dibutuhkan kerjasama oleh seluruh pihak baik pemerintah, para intelektual dan dunia pengusaha. Pemerintah bertugas menetapkan regulasi yang berkaitan dengan ekonomi kreatif dan memberikan ruang kepada masyarakat untuk menggali kreatifitas masyarakat yang bisa bersumber dari nilai budaya daerah masing-masing.

Salah satu lini bisnis di Indonesia yang memiliki perkembangan cukup baik adalah bisnis kerajinan tangan. Kekayaan alam yang begitu melimpah dan mengahasilkan penambahan pengahsilan dengan pemanfaatan limbah hasil laut . Dengan begitu produk kerajinan tangan juga banyak dibuat utamanya di beberapa wilayah seperti tempat pariwisata serta kota besar di Indonesia. Inilah yang kemudian mendorong banyak pihak untuk mencoba peluang bisnis yang satu ini. Salah satu nya adalah Kelurahan Tanjung Uban Utara Kecamatan Bintan Utara Kabupaten Bintan Kepulauan Riau.

Selama ini masyarakat umumnya terutama pengrajin belum mengetahui ternyata dalam pemasaran tersebut ada startegi yang dilakukan agar produk yang dihasilkan bisa bersaing dengan produk lain seperti kuliner, melalukan pemasaran secara otodidak dan menunggu pembeli, diharapkan dengan kegiatan ini pengrajin ketrampilan tangan bisa lebih produktif lagi.

Usaha ekonomi masyarakat yang memiliki potensi untuk dipasarkan dan dikembangkan dengan manajemen pemasaran yang lebih luas. Bentuk yang ada sudah bagus, dan perlu ditingkatkan lagi khususnya yang menyangkut produk, harga, promosi dan distribusinya. Desain kerajinan tangan masyarakat cukup menarik dan perlu ditingkatkan penjualan di pasar, baik pasar lokal maupun potensi pasar luar negeri, sehingga potensi pasar semakin luas. Strategi yang diterapkan untuk memasuki pasar adalah bauran pemasaran (marketing mix), bagaimana produk bisa memiliki keunggulan bersaing dan diminati konsumen

Permasalahan yang di hadapi oleh pengerajin dan pengusaha kerajinan tangan yaitu belum memahami sepenuhnya bagaimana usaha kerajinan tangan yang dihasilkan bisa memenuhi kebutuhan dan keinginan konsumen serta bisa terjual dan sampai ke tangan konsumen serta di sukai dan di kenal konsumen luas. Karena kurangnya pemahaman dan pengetahuan inilah yang menyebabkan kehilangan peluang bisnis bagi pengerajin dan pengusaha kerajinan tangan.

Secara rinci kendala dalam pemasaran produk kerajinan tangan adalah dari faktor promosi dan packaging (kemasan) dalam mengirimkan produk sampai ke konsumen yang tersebar. Untuk itu menyelesaikan masalah yang timbul maka di berikan pemahaman akan aspek marketing mix, baik secara teori atau pelatihan, dengan demikian diharapkan, apa yang dihasilkan oleh Pengrajin Ketrampilan Tangan yang ada bisa berkembang lebih baik. Kerajinan tangan dari limbah hasil laut memiliki potensi yang bagus, maka dengan demikian perlu pendampingan yang berkelanjutan.

Target dari hasil pelaksanaan kegiatan Pengabdian Kepada Masyarakat khususnya masyarakat ini diharapkan adalah :Pemahaman aspek bauran pemasaran 
(marketing mix) kerajinan tangan pada masyarakat pengrajin terutama ibu-ibu rumah tangga dan remaja putri di kelurahan Tanjung Uban Utara Kecamatan Bintan UtaraMampu mengaplikasikan proses bauran pemasran pada usaha kerajinan tangan yang dijalankan, berdasarkan kebutuhan dan keinginan konsumen.

\section{METODE}

\section{Waktu dan Tempat}

Kegiatan dilaksanakan pada tanggal 22 Juli 2020 di Desa TanjungUban Utara, kecamatan Bintan Utara Kabupaten Bintan, Provinsi kepulauan Riau.

\section{Prosedur Pelaksanaan dan Analisis Data}

Metode pelaksanaan kegiatan adalah berupa wokshop untuk memberikan Pelatihan Aspek Marketing Mix dimana memberikan penjelasan tentang produk yang dihasilkan harus beragam dan memiliki kualitas yang baik, dan bagaimana harga dalam satuan produksi diperhatikan baik biaya bahan baku sampai biaya tenaga kerja, serta bagaimana mempromosi produk agar di kenal dan disukai konsumen dan bagaimana mendsitribusi produk yang dihasilkan sampai ke tangan konsumen.

Kegiatan yang dilakukan meliputi: persiapan, pelaksanaan pelatihan, evaluasi kegiatan dan pembuatan laporan.

1. Persiapan

Pada tahap ini kegiatan yang dilakukan antara lain pada Tabel 1.

2. Pelaksanaan kegiatan

Tahapan pelaksanaan yang ditawarkan dapat dilihat berdasarkan kerangka pemecahan masalah Gambar 1.

3. Evaluasi kegiatan dan keberlanjutan program

Evaluasi program dilakukan untuk mengetahui hasil dan progress dari pelaksanaan program yang telah direncanakan. Evaluasi ini dilakukan dengan cara membandingkan kondisi sebelum program dilaksanakan dan kondisi setelah program dilaksanakan.
Secara rinci, evaluasi program dapat dilihat berdasarkan tabel tabel 2 .

Setelah keseluruhan program selesai dilaksanakan, maka penting untuk direncanakan keberlanjutan program tersebut. Adapun keberlanjutan program di lapangan setelah kegiatan PKM selesai dilaksanakan meliputi:

a. Monitoring beberapa progress penjualan produk kerajinan tangan yang ikut sebagai peserta pelatihan

b. Monitoring penerapan strategi pemasaran dalam kegiatan bisnis usaha kerajinan tangan

c. Melakukan pendampingan bagi peserta yang masih kesulitan dalam memasarkan produknya

d. Melayani komunikasi, baik secara langsung atau tidak (telepon, WhatsApp atau email) jika ada pertanyaan yang disampaikan oleh peserta.

Pelaksanaan pelatihan aspek marketing mix dalam bentuk Wokshop untuk usaha kerajinan tangan dengan memanfaatkan potensi alam Kecamatan Bintan Utara dalam hal ini berfokus pada Kelurahan Tanjung Uban Utara. Bantuk pelatihan pembrian materi dilaksanakan pada tanggal 25 Juli 2020 di Posko Kerajinan Tangan PKK Kelurahan Tanjung Uban Utara. Adapun peserta adalah ketua kelompok kosentrasi kerajinan tangan. 
Tabel 1. Tahapan persiapan.

Pra Survey

Analisis situasi

Pembentukan tim PKM

Pembuatan Proposal

Koordinasi Tim

\section{Tahapan Persiapan}

Identifikasi permasalahan dan kebutuhan pelaku Kerajinan Tangan dalam memahami marketing mix untuk memasarkan produknya terutama yang belum memiliki pasar dan termasuk pebisnis baru

Sebelum kegiatan dilakukan terlebih dahulı dilakukan pretest pada pengrajin dan pelakı usaha industri kecil yang ada di Bintan Utarc untuk melihat sampai sejauh mana memaham strategi pemasaran dalam hal ini baurar pemasaran (marketing mix) terhadap produknya.

Pembentukan Tim disesuaikan dengan jenis kepakaran untuk menyelesaikan permasahan pelaku pelaku Kerajinan Tangan

Pembuatan proposal untuk menawarkan solusi permasalahan dan penyediaan dana untuk pelaksanaan PKM

Perencanaan pelaksanaan program secara konseptual, operasional dan job description dari Tim

\section{Tahap pelaksanaan}

\section{(Kegiatan dilaksanakan )}

Pemaparan materi mengenai membangun mindset bisnis dan Kegiatan dilaksanakan melalui pemaparan materi dan diskusi (60 menit)

strategi pemasaran melalui

marketing mix

Pemaparan materi tentang tips dan

kiat dalam bisnis kerajinan tangan

Kegiatan dilaksanakan melalui pemaparan materi dan diskusi (60 menit)

\section{Evaluasi Program}

Dilakukan dengan membandingkan kondisi sebelum melakukan kegiatan dan sesudah pelaksanaan program. Indikator keberhasilan program dengan adanya perubahan positif beberapa pelaku usaha setelah pelaksanaan sosialisasi dan pelatihan

\section{Pelaporan}

Penyusunan laporan dilakukan sebagai bentuk pertanggungjawaban atas pelaksanaan program PKM 


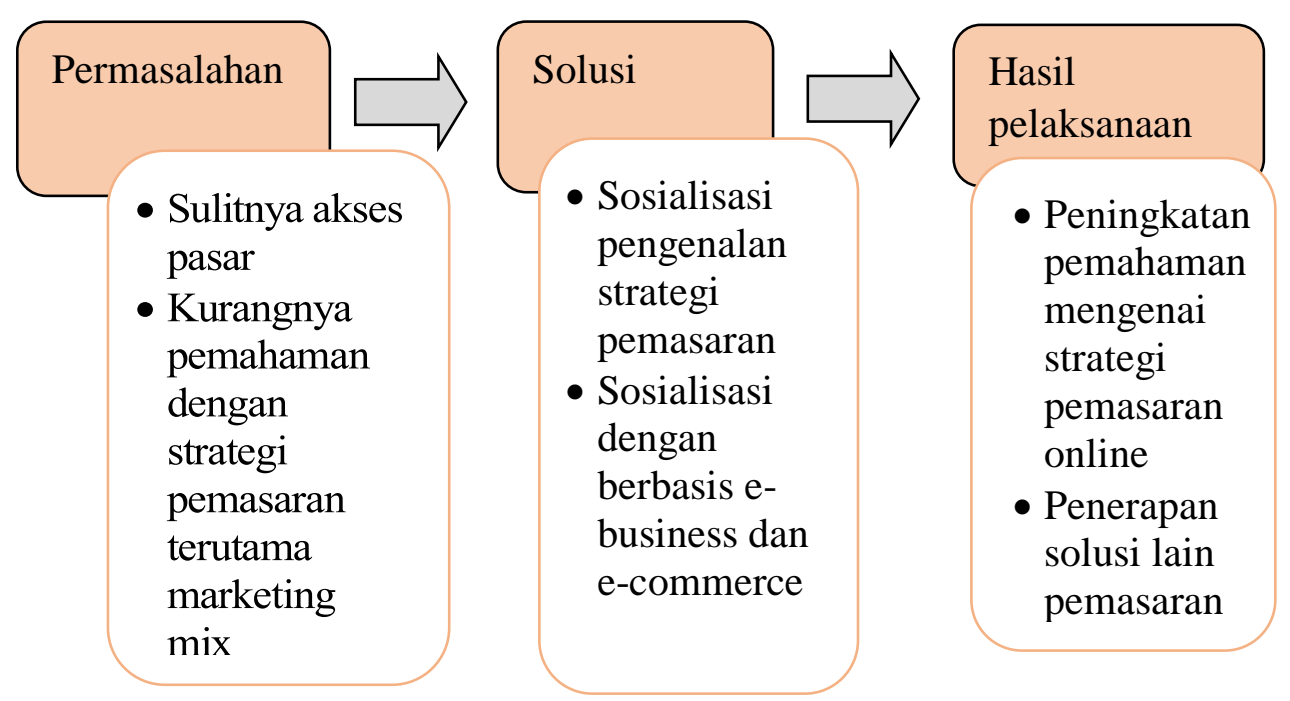

Gambar 1. Tahapan pelaksanaan pemecahan masalah

Tabel 2. Evaluasi program dan keberlanjutan program

\begin{tabular}{|c|c|c|c|c|}
\hline No & Program & Indikator & Kriteria & Instrumen \\
\hline 1. & $\begin{array}{l}\text { Sosialisasi } \\
\text { membangun } \\
\text { mindset pemasaran } \\
\text { melalui marketing } \\
\text { mix }\end{array}$ & $\begin{array}{l}\text { Pemahaman } \\
\text { pelaku } \\
\text { Kerajinan } \\
\text { tangan } \\
\text { mengenai } \\
\text { marketing mix }\end{array}$ & $\begin{array}{l}\text { Peningkatan } \\
\text { pemahaman mindset } \\
\text { bisnis dan strategi } \\
\text { pemasaran } \\
\text { pemasaran melalui } \\
\text { marketing mix }\end{array}$ & $\begin{array}{l}\text { - Observasi } \\
\text { - Wawanca } \\
\text { ra }\end{array}$ \\
\hline 2 & $\begin{array}{l}\text { Sosialisasi } \\
\text { pemasaran dengan } \\
\text { berbasis media } \\
\text { sosial }\end{array}$ & $\begin{array}{l}\text { Pemahaman } \\
\text { pelaku } \\
\text { kerajinan } \\
\text { tangan } \\
\text { mengenai } \\
\text { pemasaran } \\
\text { online }\end{array}$ & $\begin{array}{l}\text { Penerapan solusi } \\
\text { lain pemasaran } \\
\text { produk dengan } \\
\text { online }\end{array}$ & $\begin{array}{l}\text { - Observasi } \\
\text { - Wawancara }\end{array}$ \\
\hline 3 & $\begin{array}{l}\text { Sosialisasi tentang } \\
\text { tips dan kiat } \\
\text { memasarkan } \\
\text { kerajinan tangan }\end{array}$ & $\begin{array}{l}\text { Pemahaman } \\
\text { pelaku pengrajin } \\
\text { tips dan kiat } \\
\text { keberhasilan } \\
\text { memasarkan } \\
\text { hasil kerajinan } \\
\text { tangan }\end{array}$ & $\begin{array}{l}\text { Peningkatan } \\
\text { pemahaman tips dan } \\
\text { kiat sebagai strategi } \\
\text { pemasaran dalam } \\
\text { kegiatan usaha } \\
\text { bisnis kerajinan } \\
\text { tangan }\end{array}$ & $\begin{array}{l}\text { - Observasi } \\
\text { - Wawancara }\end{array}$ \\
\hline
\end{tabular}

\section{HASIL DAN PEMBAHASAN}

Dalam kegiatan ini pengerajin tangan dapat mengetahui bagaimana cara memasarkan produk yang mereka hasilkan agar terjual dan dikenal di pasaran, dimana pelatihan pemberian materi dalam hal pengetahuan tentang marketing mix yang dikenal dengan 1). Produk: artinya kombinasi barang dan jasa yang ditawarkan kepada pasar atau konsumen dalam hal ini berupa keragaman produk, kualitas, desain dan kemasan. 2) Harga merupakan jumlah uang yang harus dibayar oleh konsumen, namun dalam hal ini harga yang ditentukan oleh produsen dalam satu unit produk dengan mengakumulasikan keseluruhan pengeluaran dalam memproduksi produk. 3) promosi yang 
artinya mengkomunikasikan dan membujuk konsumen untuk membeli produk yang dihasilkan dengan berbagai sara berupa menyampaikan keunggulan produk yang dihasilkan. 4) Distribusi yaitu menyalurkan barang dari produsen ke konsumen dimana produk yang dihasilkan sampai ke tangan konsumen dalam jangka waktu yang singkat.

Selanjutnya menurut Kotler (2013), Marketing mix is the set of marketing tools that the firm uses to pursue its marketing objectives in the target market, maksudnya Bauran pemasaran (marketing mix) adalah sejumlah alat-alat pemasaran yang digunakan perusahaan untuk menyakinkan obyek pemasaran atau target pasar yang dituju. Wilayah Keputusan Strategi dalam Empat-P.
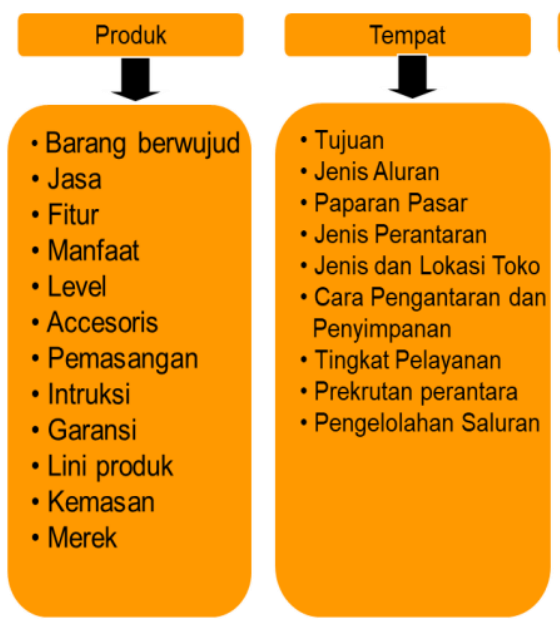

Gambar 2. Wilayah keputusan strategi empat-P

Dalam menganalisa konsumen terhadap suatu produk harus diketahui faktor-faktor yang mempengaruhi sampai pada keputusan dan kegiatan fisik, yang mempengaruhi sampai pada kepuasan untuk membeli. Variabel pemasarandibagimenjadi empat kelompok yang luas, yang disebut 4P dalam pemasaran, yaitu produk (product), harga (price), distribusi (place), dan promosi (promotion) menurut Kotler dan Armstrong (2014).

\section{Produk (Product)}

Produk-produk yang dipasarkan sebahagian besar adalah produk yang bisa diraba,terutama barang -barang produksi yang dapat dibeli oleh masyarakat. Upaya sebuah perusahaan untuk membedakan
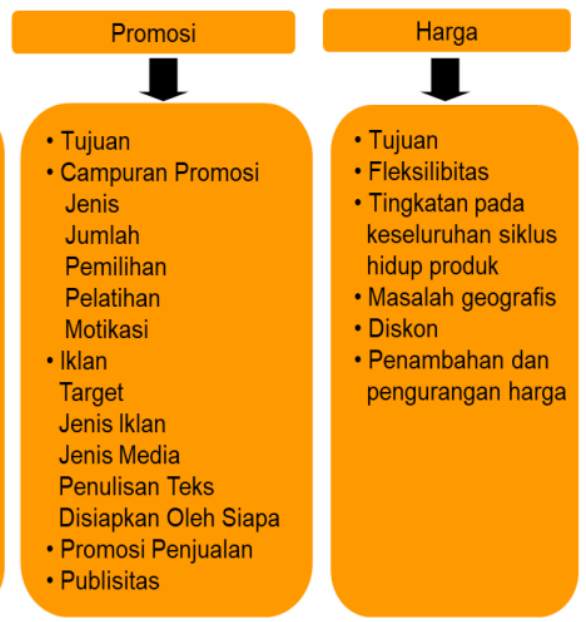

produknya dari produk pesaing agar produknya tersebut lebih menarik bagi konsumen.

2. Harga (Price)

Menentukan harga,adalah tahapan yang harus dilakukan setelah barang dan biaya produksi diketahui. Faktor - factor yang mempengaruhi kebijakan penetapan harga:Yang pertama tingkat harga yang di tentukan oleh perusahaan lain yang memproduksi barang yang sama perlu di perhatikan dalam penetapan harga. Yang kedua, apakah harga ditetapkan berbeda atau sama dengan yang ditetapkan oleh produsen - produsen barang yang sama

\section{Promosi (Promotion)}

Mempromosikan produk agar dikenal dan dibeli oleh konsumen serta membujuk para konsumen membeli barang tersebut

4. Distribusi (Place)

Artinya menyebarkan produk ke berbagai tempat. Apabila pasaran bersifat local, yaitu meliputi daerah di sekitar tempat memproduksi, pemasaran akan dilakukan sendiri oleh produsen. Contoh: petani,peternak ayam, dan produksi kecil lainnya biasanya memasarkan sendiri barang yang diproduksikan. Biaya pemasaran murah, dan harga yang ditetapkan tidak perlu mempertimbangkan biaya pemasaran. Jenis barang yang dijual juga menentukan 
saluran distribusi yang digunakan. Bahan makanan yang mudah rusak,seperti makanan dan minuman segar, biasanya dipasarkan sendiri oleh pembuatnya.

Adapun solusi untuk mengatasi masalah yang dialami oleh pengusaha kerajinan tangan Kecamatan Bintan Utara saat ini adalah dengan menyediakan sebuah forum sosialisasi dan pelatihan sebagai bentuk pengabdian kepada masyarakat. Pelaksanaan kegiatan Pengabdian Kepada Masyarakat, dalam hal ini sasarannya adalah usaha rumahan kerajinan tangan yang memanafaatkan potensi alam Bintan, yang terdiri dari ibu-ibu dan bapak bahkan remaja yang tertarik dengan usaha tersebut, dan pelaku usaha muda dengan jumlah maksimal 30 orang peserta. Dengan keadaan pandemi Covid-19, dan protokol kesehatan yang diterapkan pada Kabupaten Bintan terutama di Kelurahan Tanjung Uban Utara maka tim hanya diizinkan untuk menemui ketua kelompok yang masih aktif

\section{Cara Menjalankan Usaha Kerajinan \\ Tangan}

- Apabila modal yang dimiliki terbatas Anda bisa membatasi penjualan handicraft pada segmen tertentu, seperti aksesoris untuk remaja dan terbuat dari kulit atau kayu (potensi Bintan dengan hasil laut)

- Mencari informasi seputar handicraft unik dan temukan ciri khas yang unik sebagai ikon anda.

- Berikan sentuhan pribadi untuk produk Anda, dengan menambahkan kemasan yang cantik atau unik dengan bahan daur ulang.

- Mengikuti bazar tentang handicraft dan jalin relasi dengan para pengrajin handicraft lain untuk saling berbagi informasi seputar handicraft.

- Anda dapat menjualnya hasil kerajinan Anda dengan memajangnya di media social ( Facebook, Instagram, Twitter, dll)

\section{Kiat-Kiat Sukses Berbisnis Kerajinan Tangan}

1. Mulailah dengan hal yang disukai

Pemula hanya memikirkan keuntungan, kemudian mencari pasaran supaya bisa terjual dengan segera. jika memandang dari sisi kreatifitas seni, atau Anda suka membuatnya. Hal ini nantinya akan membuat Anda tetap semangat untuk berkarya sambil menunggu kreasi Anda dilirik kembali konsumen

\section{Kenalilah pasar}

Anda bisa mencari tahu informasi terkait harga yang pantas untuk hasil kreasi Anda. Dengan cara ini, Anda tidak akan keliru menarif hasil kreasi, misalnya kemahalan sehingga konsumen enggan membeli, atau kemurahan sehingga memberikan keuntungan yang minim.

3. Temukan pasar untuk hasil kerajinan Anda

Jangan pernah beranggapan jika kerajinan tangan akan selalu diminati sehingga Anda memaksakan diri untuk membuatnya. Ingat, tidak selalu produk menarik ini akan dilirik oleh konsumen sekitar sehingga sia-sia saja jika dilakukan. Cara terbaik untuk sukses menekuni Peluang usaha kerajinan tangan ini adalah mencari tahu pelanggan mana yang tertarik dengan hasil kreasi Anda. Setelah menemukannya, silahkan kembangkan kreasi dan pasarkan di lokasi tersebut

\section{Berinovasi}

Anda disarankan untuk selalu bertukar pikiran atau menimba ilmu dengan sesama pengrajin. Tujuannya adalah untuk memperoleh solusi dari setiap masalah yang dihadapi. Selain itu, mulailah usaha secara perlahan namun pasti. Hal ini berkaitan langsung dengan strategi dan keuangan supaya dana tidak habis tanpa mendapatkan hasil apa-apa

5. Perluas wawasan dan mulailah usaha secara bertahap

Anda disarankan untuk selalu bertukar pikiran atau menimba ilmu dengan sesama pengrajin. Tujuannya adalah 
untuk memperoleh solusi dari setiap masalah yang dihadapi. Selain itu, mulailah usaha secara perlahan namun pasti. Hal ini berkaitan langsung dengan strategi dan keuangan supaya dana tidak habis tanpa mendapatkan hasil apa-apa.

\section{Tips memelihara proses bisnis}

- Pantau competitor/Pesaing anda

- Belajar dari praktek yang terbaik

- Ubahlah sesuatu yang rumit menjadi sederhana.

Media yang bisa dilakukan untuk memasarkan produk apalagi dalam masa pademi Covid-19, agar usaha kerajinan tangan yang selama ini bergerak, tiba-tiba seperti tidak punya nyali untuk bergerak, sebagaimana kegiatan Pengabdian kepada masyarakat diperoleh bahwa pemasaran online ini sebagai strategi pemasaran yang menarik dan berbiaya rendah (Iranita dan Firmansyah, 2018). Disarankan salah satu media sodial yang bisa digunakan adalah sebagai berikut:
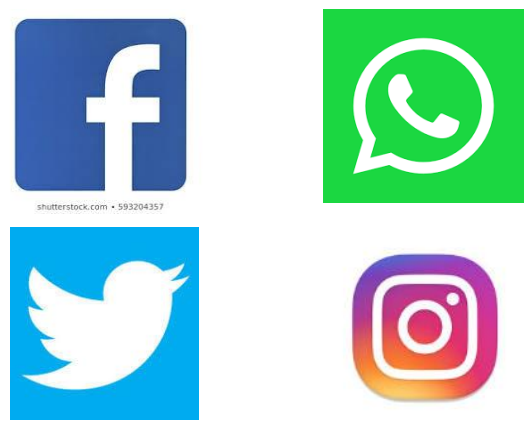

\section{KESIMPULAN}

1. Pengrajin tangan kaleurahn Tanjung Uban Utara minimal mengetahui dan memahami bahwa ada proses startegi pemasaran salah satunya adalah marketing mix dimulai dari produk, price, promosi, distribusi,
2. Pengrajin tangan telah mengetahui ttip dan kiat berhasil dalam bisnis kerajinan tangan, jika ditekuni lebih seius maka tidak hanya berdampak pada peningkatan pengahasilan pengrajin itu sendiri tetapi juga membuka peluang menambah pendapatan daerah.

\section{UCAPAN TERIMAKASIH}

Terimakasih kepada Universitas Maritim Raja Ali Haji, melalui Lembaga Penelitian Pengabdian dan Penjaminan Mutu yang telah memberikan hibah PKM pendanaan internal PKM bagi terselanggarakannya kegiatan pengabdian kepada masyarakat ini.

\section{DAFTAR PUSTAKA}

Batam News, 2019. Road Safety Melenial tahun 2019. Polda Provinsi Kepulauan Riau.

BPS-Kepri (2016), Perkembangan pertumbuhan Ekonomi Provinsi Kepulauan Riau

Iranita dan Lia Suprihartini, 2016, Pengantar Praktis Manajemen Pemasaran, cetakan 1, ISBN. 978-602-6770-30-1, Penerbit. UmrahPress, Tanjungpinang

Kotler, P.,\& Armstrong.G, 2014, Prinsipprinsip Pemasaran Jilid $1\left(13^{\text {th }}\right.$ Ed), Jakarta : Erlangga , 2013, Manajemen Pemasaran Jilid 2 (13 ${ }^{\text {th }}$ Ed), Jakarta:Erlangga dan Kevin Lane Keller, 2009, Manajemen Pemasaran, edisi ketigabelas Jilid 1, alih Bahasa oleh Bob Sabran, Penerbit Erlangga, Jakarta.

Majalah marketing, 2018, Welcome to digital Economy, edisi 01/XVIII / Januari, Gramedia :Jakarta 